\title{
PENGALAMAN HIDUP REMAJA YANG MENGALAMI PREMENSTRUAL SYNDROME (PMS) DI SMK MOCH TOHA CIMAHI
}

\author{
${ }^{1}$ Wulan Julianti, ${ }^{2}$ Dewi Marfuah, ${ }^{3}$ Suci Noor Hayati \\ ${ }^{1,2,3}$ Sekolah Tinggi Ilmu Keperawatan PPNI Jawa Barat \\ Jl. Muhammad No. 34A Bandung 40173 \\ Telp. 022-6004498, 022-6121914, Fax.022-6121914 \\ Email: wulanjulianti4@gmail.com
}

\begin{abstract}
Abstrak
Masa remaja merupakan masa peralihan dari masa kanak-kanak ke masa dewasa. Pada remaja wanita akan terjadi pematangan seksual yang ditandai dengan datangnya menstruasi. Menjelang datangnya menstruasi seorang wanita akan mengalami premenstrual syndrome (PMS). Gejala yang ditimbulkan PMS meliputi gejala afektif dan gejala somatik. Gejala tersebut akan berdampak pada kualitas hidup remaja, karena bila tidak ditangani dengan baik tentunya dapat mengganggu aktifitas remaja baik itu dirumah maupun di sekolah. Penelitian ini bertujuan untuk mengetahui bagaimana pengalaman hidup remaja yang mengalami PMS di SMK Moch Toha Cimahi. Penelitian ini menggunakan metode penelitian kualitatif dengan desain fenomenologi deskriptif, data diperoleh dari hasil wawancara. Informan dalam penelitian ini berjumlah lima orang. Data yang dikumpulkan berupa hasil rekaman wawancara dan catatan lapangan yang dianalisis dengan teknik Collaizi. Penelitian ini menghasilkan lima tema yaitu: Berbagai perubahan fisik, Psikologis dan perilaku dialami remaja saat PMS, PMS dirasakan mengganggu hubungan interpersonal dan aktivitas sosial, Penanganan non farmakologi lebih banyak dilakukan remaja saat mengalami PMS, Faktor eksternal dan internal menjadi alasan remaja saat melakukan penanganan, Gejala dirasakan berkurang setelah dilakukan beberapa penanganan. Hasil penelitian ini dapat memberikan gambaran kepada remaja mengenai pengalaman remaja dalam menghadapi PMS. Disarankan bagi tenaga kesehatan khususnya perawat untuk memberikan pendidikan kesehatan kepada remaja mengenai menstruasi dan gangguannya, khususnya premenstrual syndrome.
\end{abstract}

Kata kunci : pengalaman, remaja wanita, premenstrual syndrome

\begin{abstract}
Adolescence is the transition period from childhood to adulthood. Adolescence girls will experience a sexual maturity marked by the presence of menstruation. Before the presence of menstruation takes date, a woman will experience premenstrual syndrome (PMS). The symptoms of PMS include affective and somatic symptoms. The symptoms will result in adolescence girls' quality of life because if the symptoms are not properly treated, it will disrupt their activities whether at home or at school. The objective of this research was to adolescent experiences of premenstrual syndrome at SMK Moch Toha Cimahi. It used qualitative method with descriptive, phenomenologic design. The data were collected from the results of interview. The informant were five people. The data that had been gathered were an interview record an field note that analyzed by Collaizi technique. The results of this research revealed five themes, various physical changes psychological and behavior of adolescents experienced during PMS, PMS perceived disrupt interpersonal relationship and social activities, handling of non-pharmacological more young people do when experiencing PMS, external and internal factors become the reason a adolescent when handling, reduced symptoms felt after a few handling. The result of this research can give an idea for the adolescent regarding the adolescent experience in dealing with premenstrual syndrome. It is suggested to the physicians to conduct the counseling about PMS and its treatment for adolescence girls.
\end{abstract}

Keywords: experience, adolescence girls, premenstrual syndrome 

Julianti)

\section{PENDAHULUAN}

Masa remaja merupakan masa peralihan dari masa kanak-kanak ke masa dewasa. Setiap remaja akan mengalami perubahan baik biologis, psikologis, fisiologis maupun aspek sosial, salah satu perubahan yang dialami oleh wanita adalah perubahan pada organ reproduksi yaitu terjadinya kematangan seksual yang ditandai dengan datangnya menstruasi. Menstruasi adalah pelepasan dinding rahim (endometrium) yang disertai dengan perdarahan yang terjadi secara berulang setiap bulannya (Lubis, 2013). Salah satu gangguan yang terjadi sebelum menstruasi adalah Premenstrual syndrome (PMS).

Premenstrual syndrome (PMS) merupakan kumpulan gejala yang timbul secara siklik sebelum haid dan berakhir saat haid mulai turun, baik secara fisik, emosional maupun perilaku (Suparman, 2011). Prevalensi PMS mencakup sekitar 85\% populasi wanita usia reproduksi dan hampir separuhnya tidak berupaya mencari pertolongan medis. (Suparman, 2011). Ada beberapa faktor yang diduga menjadi penyebab timbulnya PMS diantaranya kadar hormon estrogen yang berlebih, kadar hormon progesteron yang rendah, peningkatan hormon aldosteron, renin-angiotensin serta hormon adrenal, kekurangan serotonin, kekurangan vitamin dan mineral (A, E B6, Kalsium), hipoglikemi, hiperprolaktinemia (Arisman, 2008). Penelitian yang dilakukan oleh WHO mengenai pola dan persepsi menstruasi menyatakan bahwa PMS adalah suatu fenomena yang terdapat di masyarakat. Usia, predisposisi keluarga, latar belakang sosial diperkirakan memiliki pengaruh nyata pada insiden PMS (Andrews, 2009).

Gangguan menstruasi memerlukan evaluasi yang seksama karena gangguan menstruasi yang tidak ditangani dapat mempengaruhi kualitas hidup dan aktivitas sehari-hari. Penelitian yang sudah dilakukan oleh Sianipar (2009) tentang prevalensi gangguan menstruasi pada siswi SMU di kecamatan Pulo Gadung Jakarta Timur didapatkan hasil bahwa PMS adalah salah satu keluhan yang paling banyak mengganggu aktivitas remaja di sekolah dengan hasil data yang mengalami PMS sebanyak $67 \%$ dan dismenore $33 \%$. Efek gangguan menstruasi yang dilaporkan antara lain waktu istirahat yang memanjang (54\%) dan menurunnya kemampuan belajar $(50 \%)$. Berbagai macam penanganan bisa dilakukan remaja untuk mengatasi PMS, salah satunya dengan penanganan non farmakologi seperti edukasi dan konseling, diet dan olahraga, sedangkan penanganan farmakologi nya dengan mengkonsumsi obat-obatan analgetik.

Peneliti melakukan studi pendahuluan pada tanggal 21 November 2015. Studi pendahuluan dilakukan dengan mewawancarai 5 orang remaja yang bersekolah di SMK Moch Toha Cimahi, dua dari lima remaja mengatakan apabila sedang PMS mereka sering marah-marah tidak jelas, perasaannya lebih sensitif, apabila gejala itu muncul mereka hanya mendiamkannya saja. Dua orang lainnya mengatakan sebelum menstruasi mereka sering mengalami gejala seperti sakit pada payudara, sakit kepala apabila gejala itu muncul mereka cenderung mengkonsumsi obat-obatan penghilang rasa nyeri. Satu orang remaja mengatakan pernah mengalami gejala PMS seperti sakit pada bagian perut, pusing dan nyeri payudara serta merasa kelelahan pada saat sedang belajar, untuk mengatasinya remaja tersebut hanya beristirahat untuk mengurangi rasa sakitnya tersebut. 


\section{METODE PENELITIAN}

Penelitian ini menggunakan metode penelitian kualitatif. Desain yang digunakan dalam penelitian ini adalah fenomenologi karena berfokus pada pengalaman-pengalaman subjektif mengenai pengalaman hidup remaja yang mengalami premenstrual syndrome (PMS). Penelitian ini dilaksanakan di SMK Moch Toha Cimahi. Informan dalam penelitian ini berjumlah lima orang dengan kriteria inklusi sebagai berikut:

1. Remaja berusia 15-19 tahun dan sudah menstruasi

2. Menstruasinya reguler/sudah teratur (2135 hari)

3. Remaja yang sebelum menstruasi mengalami gejala sesuai dengan skrining PMS

4. Dapat berkomunikasi dengan baik

5. Bersedia menjadi informan penelitian

Analisa data yang digunakan dalam penelitian ini menggunakan teknik Colaizzi (1978).

\section{HASIL DAN PEMBAHASAN}

Penelitian ini menghasilkan lima tema yaitu :

Tema 1. Berbagai perubahan fisik, psikologis dan perilaku dialami remaja saat PMS

Perubahan yang diungkapkan informan pada saat mengalami PMS diantaranya perubahan fisik, psikologis dan perilaku. Seperti yang telah dikemukakan oleh Andrews (2009) gejala PMS di kelompokan ke dalam tiga kategori dan wanita sering mengalami perpaduan dari gejala tersebut. Gejala tersebut diantaranya gejala fisik, gejala psikologis dan gejala perilaku. Perubahan fisik yang di rasakan informan saat PMS meliputi pembengkakan pada payudara dan kaki, sakit perut, pusing, sakit pinggang, pegal-pegal, perut kembung, munculnya jerawat, sakit leher, badan panas-panas, sakit badan dan munculnya keputihan. Berikut ini salah satu ungkapan dari informan yang mengalami pembengkakan pada payudara dan kaki:

“...Iya kaya payudara, pinggang jadi kaya membesar gitu, bengkak-bengkak jadi berat berat gitu seluruh badan teh..." (Informan 1)

Hal ini sejalan dengan teori menurut Sibaragiang (2010) bahwa PMS itu terdiri dari empat tipe salah satunya PMS tipe $\mathrm{H}$ (Hyperhydration). PMS tipe $\mathrm{H}$ di tandai dengan gejala edema (pembengkakan) ekstermitas, perut kembung, nyeri pada payudara dan peningkatan berat badan. Pembengkakan itu terjadi akibat berkumpulnya air dan jaringan di luar sel (ekstra sel) karena tingginya gula dan asupan garam.

Selain perubahan fisik, informan juga merasakan perubahan secara psikologis yang meliputi mudah marah, mudah tersinggung, sering melamun, kurang berkonsentrasi, tidak bersemangat, pelupa dan suasana hati yang mudah berubah. Berikut ini salah satu ungkapan dari informan yang mengalami perubahan secara psikologis :

“...Terus еиии... gampang marah..." (Informan 5)

“...Ya suka kesinggung gitu...” (Informan 2)

Hal ini sejalan dengan penelitian Zulaikha (2010) dengan judul "Hubungan Pengetahuan Kesehatan Keproduksi Remaja Putri Terhadap Sikap menghadapi Premenstrual Syndrome di SMA N 5 Surakarta" yang menunjukkan bahwa selain keluhan fisik, ditemukan pula keluhan yang bersifat psikologis seperti merasa lebih sensitif dan mudah marah $(18,59 \%)$.

Perubahan yang di rasakan oleh kelima informan selanjutnya adalah perubahan perilaku. Penelitian ini menunjukkan bahwa perubahan perilaku yang sering di rasakan 

Julianti)

oleh kelima informan meliputi ngidam makanan dan nafsu makan bertambah malas beraktivitas, susah tidur/insomnia, lebih banyak tidur di siang hari hipersomnia. Berikut ini salah satu ungkapan dari informan yang mengalami perubahan perilaku seperti nafsu makna bertambah :

“...Terus nafsu makan suka bertambah pengennya makan terus..." (Informan 1)

Hal ini sejalan dengan Sibaragiang (2010) bahwa PMS tipe $\mathrm{C}$ ditandai dengan rasa lapar yang berlebih, ingin mengkonsumsi makanan atau minuman yang manis-manis dan karbohidrat sederhana. Rasa ingin menyantap makanan manis dapat di sebabkan oleh stres, tinggi garam dalam diet makanan, tidak terpenuhinya asam lemak esensial (omega 6) dan kurangnya magnesium.

\section{Tema 2. PMS dirasakan mengganggu hubungan interpersonal dan aktivitas sosial}

Kelima informan mengalami dampak yang di timbulkan dari gejala PMS, dampak tersebut mengganggu hubungan secara interpersonal antara informan dengan orang lain serta mengganggu aktivitas sosial informan itu sendiri. Tiga dari lima informan mengungkapkan saat sedang mengalami PMS mereka mengalami perubahan suasana hati seperti marah-marah tanpa alasan yang jelas dan tidak ingin diganggu oleh orang lain. Hal ini jelas mengganggu hubungan secara interpersonal antara informan dengan orang di sekitarnya. Selain mengganggu hubungan interpersonal, dampak lain yang di timbulkan akibat gejala PMS adalah mengganggu aktivitas sosial informan seperti malas beraktivitas dan kurang berkonsentrasi dalam menerima pelajaran di sekolah. Makna ini didapatkan dari pernyataan ke empat informan berikut ini :
“...Ya males beraktivitas apalagi kalau mau ngerjain pekerjaan rumah, kalau di sekolah juga ngerjain pekerjaan sekolah suka males..."(Informan 1)

“...Ga konsen sih teh jadi pikiran nya teh melayang kemanaaaa gitu, pengennya teh pengen cepet-cepet pulang ajah..."(Informan 4)

Hal ini sejalan dengan penelitian Thomas (2009) bahwa gejala-gejala yang timbul akibat PMS akan berdampak negatif pada nilai akademis dan aktivitas remaja di sekolah. Sebagian besar remaja memilih tidak mengikuti pelajaran dengan alasan nyeri pada bagian perut dan mengalami perubahan suasana hati yang meningkat karena sedang mengalami PMS. Mereka juga mengatakan sulit untuk berkonsentrasi menerima pelajaran yang diberikan di sekolah.

Hal ini juga sejalan dengan hasil penelitian Wahyuni (2014) yang berjudul "Gambaran Sindroma Pramenstruasi dari Gejala Emosional dan Fisik pada Siswi SMP Muhammadiyah 1 Surakarta" bahwa dampak yang di timbulkan dari PMS ini dapat mempengaruhi hubungan siswi dengan teman yang lain, aktivitas sosial baik dilingkungan atau disekolah sehingga proses belajar siswi tersebut akan terganggu.

\section{Tema 3. Penanganan non farmakologi lebih banyak dilakukan remaja saat mengalami PMS}

Setiap informan melakukan penanganan yang berbeda-beda, berbagai macam cara untuk mengatasi PMS yang di lakukan informan sesuai dengan pengetahuan dan pengalaman mereka. Sebagian dari informan ada yang melakukan penanganan secara non farmakologi diantaranya seperti di pijat pada bagian yang nyeri, istirahat atau tiduran, mengoleskan minyak angin aromatherapy pada bagian yang nyeri, minum air hangat, 
melakukan aktivitas dan olahraga, mendengarkan musik dan memakai pembersih muka jika sedang muncul jerawat. Berikut pernyataan salah satu informan yang melakukan penaganan dengan melakukan aktivitas fisik dan olahraga :

“...Kalau misalkan untuk meredakannya mencoba untuk di gerakan aja di rumah, kaya beres-beres sama olahraga gitu" (Informan 2)

Hal ini sejalan dengan pendapat Andrews (2009) bahwa semua bentuk aktivitas fisik seperti olahraga dapat membuat wanita yang mengalami PMS menjadi lebih rileks karena pada saat berolahraga otak akan memproduksi hormon endorfin yang dapat meningkatkan perbaikan suasana hati dan mengurangi rasa cemas pada wanita yang mengalami PMS. Hal ini juga sejalan dengan penelitian Silvia (2014) yang berjudul Hubungan Pengetahuan dan Motivasi Remaja Putri dengan Penanganan Sindrom Pramenstruasi di SMA Muhamadiyah 5 Yogyakarta, dari 49 responden yang di teliti sebanyak $22(44,9 \%)$ responden melakukan penanganan yang baik hasil analisis menunjukan penanganan yang dilakukan remaja pada saat mengalami PMS di antaranya melakukan aktivitas fisik seperti olahraga, mengoleskan minyak angin pada bagian yang nyeri, istirahat atau di tidurkan, di pijat pada bagian yang nyeri, dan mengkonsumsi makanan yang bergizi untuk mencegah terjadinya sindrom pramenstruasi.

Selain penanganan secara non farmakologi, beberapa informan juga melakukan penanganan secara farmakologi dengan mengkonsumsi obat-obatan analgetik. Obat analgetik ini diperoleh dengan membeli obat di apotik atau di warung terdekat. Berikut salah satu pernyataan informan yang mengkonsumsi obat analgetik :
“...Kalau sakit perut ya kadang minum obat juga, sama dari apotek namanya alkita...” (Informan 2)

Menurut Suparman (2011) penurunan nyeri saat PMS dapat dilakukan secara farmakologi wanita yang mengalami nyeri sebelum menstruasi banyak yang dibantu dengan mengkonsumsi obat anti inflamasi non steroid (NSAID) yang menghambat produksi dan kerja prostaglandin.

\section{Tema 4. Faktor eksternal dan internal menjadi alasan remaja saat melakukan penanganan}

Kelima informan mengungkapkan bahwa alasan mereka melakukan penanganan untuk mengurangi gejala PMS di pengaruhi oleh faktor eksternal dan internal. Menurut Notoatmodjo (2007) perilaku kesehatan di pengaruhi oleh faktor eksternal dan faktor internal, faktor eksternal terdiri dari lingkungan, sosial dan budaya. Faktor internal terdiri dari pengetahuan, persepsi, motivasi, niat dan sikap. Faktor eksternal dalam penelitian ini yaitu sebagian remaja melakukan penanganan dengan meminum obat analgetik karena di sarankan oleh ibunya, selain itu ada yang di sarankan oleh kakaknya dan ada juga yang di sarankan oleh orang lain. Jadi dalam penelitian ini informan melakukan penanganan karena terpengaruhi oleh lingkungan di sekitarnya, seperti keluarga dan teman-temannya. Berikut pernyataan salah satu informan yang disarankan oleh ibunya :

“...Dikasih tau sama mamah soalnya mamah pengalaman pernah sakit kaya gitu, ya minum obat ini aja mamah juga pernah ngalamin hal yang sama..." (Informan 3)

Hal ini sejalan dengan pendapat Silvia (2014) bahwa lingkungan sekitar berperan dalam mempengaruhi penanganan PMS hal ini di 
tunjukkan oleh pesan keluarga, teman dan orang lain di sekitarnya.

Faktor internal dalam penelitian ini adalah dua dari kelima informan berpendapat apabila informan sedang mengalami PMS mereka cenderung melakukan aktivitas fisik seperti olahraga karena dengan melakukan aktivitas fisik badan akan menjadi segar. Salah satu informan berpendapat apabila informan sedang mengalami nyeri, informan tersebut cenderung untuk mengoleskan minyak angin di bagian yang nyeri karena minyak angin lebih terasa panas dan bisa mengurangi rasa nyerinya. Berikut pernyataan informan :

“...Ya mau aja da kalau sakit perut mah harus di gerakin gitu..." (Informan 4)

“...Ya kan fresh care mah panas, jadi kerasa kena perut...” (Informan 5)

Hal ini sejalan dengan pendapat Soekanto (2012) bahwa pengalaman dapat mempengaruhi perilaku seseorang karena ia sudah pernah mengalami masalah itu sehingga ia sudah mengetahui apa yang akan terjadi. Suatu yang sudah pernah dialami oleh seseorang akan menambah pengetahuan tentang apa yang di alaminya.

\section{Tema 5. Gejala dirasakan berkurang setelah dilakukan beberapa penanganan}

Penelitian ini di dapatkan hasil bahwa sebagian besar informan menyatakan gejala berkurang setelah mereka mengonsumsi obat analgetik, gejala juga berkurang saat informan selesai di pijat dan setelah di oles menggunakan minyak angin pada bagian yang nyeri gejala juga berkurang. Berikut salah satu pernyataan informan :

“...Udah aga mendingan, ngga terlalu sakit perut, hmmm engga terlalu pusing, lumayan enak, udah ringan sakitnya..." (Informan 2)
“...Enak teh, jadi ringan-ringan gitu badan teh, jadi badan teh ga pegel-pegel, jadi biasa aja weh gitu...” (Informan 5)

“...Kalau udah pake fresh care jadi mendingan..." (Informan 5)

Hal ini sejalan dengan pendapat yang di kemukakan Sari (2013) pemberian obat gosok atau minyak angin di daerah nyeri (analgetik perifer) mempunyai keuntungan misalnya tidak ada efek lintas pertama gastrointestinal dan hati, daya penerimaan lebih baik di banding peroral, dan pemberian obat dapat dihentikan pada setiap waktu dengan menghilangkan sistem penghantar obatnya.

Penggunaan obat gosok atau minyak angin juga dapat meningkatkan relaksasi otot-otot dan mengurangi nyeri akibat spasme atau kekakuan serta memberikan rasa hangat lokal. Pada umumnya panas cukup berguna untuk pengobatan. Panas meredakan iskemia dengan menurunkan kontraksi dan meningkatkan sirkulasi, juga dapat menyebabkan pelepasan endorfin tubuh sehingga memblok transmisi stimulasi nyeri. Sebagian dari informan juga mengungkapkan gejala masih tetap terasa meskipun informan sudah di pijat dan mengkonsumsi obat analgetik.

\section{PENUTUP}

\section{Kesimpulan}

Tema yang teridentifikasi dalam penelitian ini berjumlah lima tema dari lima informan yang telah diwawancarai.

\section{Tema 1 Berbagai perubahan fisik, psikologis dan perilaku dialami remaja saat PMS}

Pada saat PMS remaja mengalami beberapa perubahan yang terjadi pada dirinya. Perubahan tersebut meliputi perubahan fisik, psikologis dan perilaku. 
Perubahan fisik yang dirasakan seperti sakit perut, pusing, pegal-pegal, timbul jerawat, sakit pinggang, sakit badan, perut kembung, pembengkakan payudara dan pinggang, keputihan, demam dan sakit leher. Selanjutnya perubahan secara psikologis, remaja akan mudah marah/emosi, kurang berkonsentrasi, melamun, pelupa, tidak bersemangat, suasana hati yang mudah berubah dan mudah tersinggung pada saat mengalami PMS. Selain perubahan fisik dan psikologis, remaja juga akan mengalami perubahan secara perilaku seperti malas beraktivitas, insomnia dan hipersomnia, nafsu makan bertambah dan menginginkan makanan tertentu.

\section{Tema 2 PMS dirasakan mengganggu hubungan interpersonal dan aktivitas sosial}

Perubahan yang dialami remaja pada saat PMS akan berdampak pada kualitas hidupnya, diantaranya mengganggu hubungan interpersonal remaja dengan orang di sekitarnya seperti marah-marah tanpa alasan yang jelas dan tidak mau di ganggu oleh orang lain. Selain mengganggu hubungan interpersonal dampak yang di timbulkan juga mengganggu aktivitas sosial informan seperti malas beraktivitas dan kurang konsentrasi saat sedang belajar.

\section{Tema 3 Penanganan non farmakologi lebih banyak dilakukan remaja saat mengalami PMS}

Dari dampak yang ditimbulkan akibat PMS para remaja melakukan beberapa penanganan untuk mencegah agar dampak tersebut tidak semakin parah. Beberapa remaja melakukan penanganan secara non farmakologi dan farmakologi. Penanganan non farmakologi meliputi di pijat pada bagian yang nyeri, melakukan aktivitas, beristirahat atau tiduran, mengoleskan minyak angin pada bagian yang nyeri, meminum air hangat, memakai pembersih muka jika muncul jerawat dan mendengarkan musik. Sedangkan upaya farmakologinya dengan mengkonsumsi obat-obatan analgetik.

\section{Tema 4 Faktor eksternal dan internal menjadi alasan remaja saat melakukan penanganan}

Alasan remaja melakukan penanganan tersebut di pengaruhi oleh dua faktor diantaranya faktor eksternal dan faktor internal. Faktor eksternal meliputi di sarankan oleh orang terdekatnya seperi ibu, saudara dan orang lain. Sedangkan faktor internalnya adalah salah satu informan berpendapat dengan melakukan aktivitas fisik badan akan menjadi segar selain itu salah satu informan juga berpendapat bahwa dengan mengoleskan minyak angin di bagian yang nyeri hal itu bisa membuat nyeri menjadi berkurang.

\section{Tema 5 Gejala dirasakan berkurang setelah dilakukan beberapa penanganan}

Setelah melakukan beberapa penanganan untuk mengatasi gejala PMS, gejala mulai berkurang saat remaja mengkonsumsi obat analgetik pada saat sakit perut, pusing dan demam, gejala juga berkurang pada saat informan mengoleskan minyak angin pada bagian yang nyeri, selain itu setelah di pijat pegal-pegal di seluruh tubuh juga berkurang. Tetapi sebagian dari remaja merasa bahwa gejala di rasa tidak berkurang ketika setelah di pijat pegalpegal di seluruh tubuh tidak berkurang dan setelah mengkonsumsi obat, sakit di perut tetap ada. 
Pengalaman Hidup Remaja yang Mengalami Premenstrual Syndrome (PMS) di SMK Moch Toha Cimahi (Wulan Julianti)

\section{Saran}

1. Bagi Remaja

Diharapkan informan mau meningkatkan pengetahuan tentang PMS seperti membaca buku kesehatan, bertanya kepada petugas kesehatan ataupun menggunakan fasilitas seperti internet dan mencari informasi tentang penanganan atau tindakan yang baik dalam menangani PMS.

2. Bagi SMK Moch Toha Cimahi

Hasil penelitian dapat dijadikan bahan pertimbangan untuk memfasilitasi pelayanan kesehatan seperti UKS di sekolah. Merencanakan kerja sama dengan puskesmas setempat dan tenaga kesehatan lainnya untuk memberikan penyuluhan kesehatan mengenai menstruasi dan gangguannya.

3. Bagi Tenaga Kesehatan

Bagi tenaga kesehatan khususnya perawat disarankan untuk memberikan pendidikan kesehatan kepada remaja mengenai menstruasi dan gangguannya, khususnya premenstrual syndrome.

4. Bagi Peneliti Selanjutnya

Bagi peneliti selanjutnya dapat menjadi bahan referensi dan pertimbangan serta perlu adanya penelitian lanjutan melalui eksplorasi mendalam tentang faktor yang mempengaruhi resiko terjadinya PMS, seperti faktor genetik karena PMS lebih rentan diderita oleh wanita dengan riwayat PMS pada anggota keluarga wanita lainnya.

\section{DAFTAR PUSTAKA}

Andrews, Gilly. (2009). Buku Ajar Kesehatan Reproduksi Wanita (edisi 2). Jakarta: EGC.

Arisman. (2008). Gizi dalam Daur Kehidupan (edisi 2). Jakarta: EGC.
Lubis, N. L. (2013). Psikologi Kespro Wanita dan Perkembangan Reproduksinya. Jakarta: Kencana Prenada Media Group.

Notoatmodjo. (2007). Promosi Kesehatan Teori \& Aplikasi. Jakarta: Rineka Cipta.

Sari, N. (2013). Pengalaman Mengatasi Nyeri Menstruasi pada Remaja di MA Darul Ulum Demak. Skripsi Fakultas Ilmu Keperawatan dan Kesehatan Universitas Muhammadiyah Semarang.

Sianipar, O., dkk. (2009). Prevalensi Gangguan Menstruasi dan Faktorfaktor yang Berhubungan pada Siswi SMU di Kecamatan Pulo Gadung Jakarta Timur. Majalah Kedokteran Indonesia, 59, (7), 309-310. 14 November 2015. http://indonesia. digitaljournals.org/index.php/idnmed/ article/download/653/648

Sibagariang, E.E., Pusmaika, R., Rismalinda. (2010). Kesehatan Reproduksi Wanita. Jakarta: Trans Info Media.

Silvia, M. (2014). Hubungan Pengetahuan dan Motivasi Remaja Putri dengan Penanganan Sindrom Pramenstruasi di SMA Muhamadiyah 5 Yogyakarta.

Soekanto. (2012). Promosi Kesehatan Kebidanan. Jakarta: Rineka Cipta.

Suparman, E. (2011). Premenstrual Syndrome. Jakarta: EGC.

Thomas, Silvy. (2009). Assessing the Knowledge of Premenstrual Syndrome and its Management Among Adolescent Girls. Master's degree in nursing ST. John's college of nursing.

Wahyuni. (2014). Gambaran Sindroma Pramenstruasi dari Gejala Emosional 
dan Fisik pada Siswi SMP Muhammadiyah 1 Surakarta. Profesi. (11). 4-5. 9 Mei 2016. http:// ejournal.stikespku.ac.id/index.php/mp $\mathrm{p} /$ article/view/73

Zulaikha, F. (2010). Hubungan Pengetahuan Kesehatan Keproduksi Remaja Putri terhadap Sikap Menghadapi Premenstrual Syndrome di SMA N 5 Surakarta. Karya Tulis Ilmiah Program Studi D IV Kebidanan Fakultas Kedokteran Universitas Sebelas Maret. 